„Bohemistyka” 2020, nr 4, ISSN 1642-9893

\title{
$\begin{array}{lllllll}\mathbf{K} & \mathbf{R} & \mathbf{O} & \mathbf{N} & \mathbf{I} & \mathbf{K} & \mathbf{A}\end{array}$
}

Grażyna BALOWSKA

DOI: $10.14746 /$ bo. 2020.4 .10

Uniwersytet Opolski

Marie KRČMOVÁ

Masarykova univerzita

\section{Významné životní jubileum profesorky Marie Krčmové}

Dobrym zwyczajem czasopism naukowych jest publikowanie artykułów jubileuszowych z okazji tzw. „okrągłych” rocznic urodzin osobowości nauki. Teksty te jako specyficzny gatunek charakteryzują się stosunkowo stałą strukturą oraz określonym doborem faktów. Biorąc bowiem pod uwagę fakt, że Jubilat przeżył już kilka takich „okrągłych” rocznic, treści zawarte w artykułach jubileuszowych Jemu poświęconych w większości powtarzają się: droga zawodowa, kariera naukowa, działalność publikacyjna czy aktywność organizacyjna. Dlatego też zdecydowaliśmy się, na co Jubilatka łaskawie wyraziła zgodę, na inną formę uświetnienia rocznicy urodzin dostojnej Jubilatki - na wywiad, który pozwala na zadanie także mniej formalnych pytań. Z Panią Profesor PhDr. Maria Krčmova, CSc., emerytowanym profesorem Wydziału Filozoficznego Uniwersytetu T.G. Masaryka w Brnie i Wydziału Filozoficznego Uniwersytetu Ostrawskiego w Ostrawie, rozmawia Grażyna Balowska.

GB: W grudniu tego roku obchodzi Pani Profesor jubileusz 80 lat życia ${ }^{1}$. Jest to wiek, który określa się jako czcigodny, dostojny, piękny, wyjątkowy. Ale jak to wszystko się zaczęlo?

MK: Jako u každého - narozením. Trošku výjimečné je jen datum 24. prosince, nevhodné pro maminku, která si neužila vánočního kapra, pro tatínka, který běžel do porodnice okouknout miminko (prý se dost zděsil, novorozeňata nehřeší krásou), a samozřejmě i pro mne. Dárky se tak nějak spojují s tím pod stromečkem, radost je také spojená. V okamžiku, když jsem si to uvědomila to bylo ovšem o pár let později - se našlo řešení: $\mathrm{k}$ narozeninám ráno, stro-

${ }^{1}$ Por. tnp. artykuły Michal Kř́stek, Martin Schacherl, Jubileum prof. Marie Krčmové, „Bohemistyka” 2015, nr 4, s. 400-401, oraz Grażyna Balowska, Jubileusz Profesor Mari "Krčmovej, , ,Bohemistyka” 2010, nr 2, s. 159-161, w których znajduje się wykaz ważniejszych prac Pani Profesor. Pełna bibliografia publikacji Jubilatki będzie zamieszczona w tomie Jej prac, który znajduje się w przygotowaniu. 
meček večer. Dnes platí alternativní řešení, dárky v předvečer. Velmi vhodné pro kytice, které mohu užít skutečně po celé svátky.

GB: To rzeczywiście wyjątkowa data. Czy była przyczyną jakichś komplikacji w życiu Pani Profesor?

MK: To jistě ne, datum si však pamatují kolegové a pravidelně přejí. Jen jak jdou roky, gratulantů ubývá. Bohužel.

GB: Grono kolegów zyskujemy w kręgach zawodowych, ale wcześniej także w okresie nauki w szkole podstawowej czy średniej. Czy pamięta Pani Profesor pierwsze lata szkolne?

MK: Ve škole získáme spíš kamarády, i když někdy celoživotní. Já sama patřím $\mathrm{k}$ ročníkům, které měly kratší povinnou školní docházku, pouhých 8 let základní školy a 3 další roky do maturity. Zkrácení bylo dík/vinou koncepce jedenáctiletek a bylo realizováno skutečně geniálně, jeden ročník se prostě vypustil a látku, která patřila do osnov, nikdo nikdy soustavně neprobral. To, co se zanedbalo od začátku školní docházky, se už nikdy nedohoní, špatné základy umožní se poznatky sice naučit třeba zpaměti, ale ne zvládnout. To ovšem zjistíme až časem.

GB: Pamięta Pani Profesor swoich pierwszych nauczycieli?

MK: Na všechny jistě ne, ale s odstupem času jsem si vědoma, jak je důležitý dobrỳ učitel, znalý předmětu, který umí látku podat. Byli učitelé dobří i horší, všichn museli proplout složitými dobami první poloviny 50. let. Vzpomínáme se spolužáky, kterých pomalu ubývá, třeba na matematika, lidsky výborného, ale oborově neštastného pana učitele Veselíka, aprobací latináře, který s matematikou, která mu byla naráz přidělena, dost zápasil. Já sama pak na češtinářku paní Škyř́kovou, která v klidu probírala i věci, jež v osnovách nebyly. Hůře na tom byly cizí jazyky. Ruštinu mě na počátku učila paní, která absolvovala nějaký rychlokurz, a i když ruština měla docela dobrou dotaci hodin, na špatných základech se těžko buduje poznání. Ostatní jazyky na tom byly mnohem hưře a naučené fráze $\mathrm{z}$ němčiny těžko uplatním. Tehdy to tolik nechybělo, protože cestování bylo omezené, ale dnes už těžko něco doženu. Mohu v angličtině, kterou jsem se začala učit až po padesátce, nebo v němčině číst, ale nepromluvím.

GB: Czy brakuje tego Pani Profesor? Przecież jest Pani bohemistką i slawistką Bardzo dobrze mówi Pani na przykład po polsku i po rosyjsku.

MK: Schází-zvláště dnes, kdy je nutno znát novou odbornou literaturu ve světových jazycích. V samém oboru však nedostatek nepocituju. Po maturitě jsem byla přijata na obor čeština-ruština na Filozofické fakultě brněnské univerzity, která měnila jména - po r 1990 se vrátila k původnímu názvu Masarykova univerzita, a byla tu přes různé peripetie kontinuita oborů navazující na doby před válkou. Důležité bylo, že moji učitelé a později kolegové udržovali neformáln vztahy mezi obory, nejen slavistickými. Byli mladí, začali studovat po válce, měli o filologii opravdový zájem a dovedli alespoň některé z nás nadchnout. Už také nejsou mezi námi - starší obecní lingvisté Václav Machek a Adolf Erhart, mladší rusisté Stanislav Žaža a Roman Mrázek, slavista Radoslav Večerka, bohemisté Arnošt Lamprecht, Jan Chloupek, Milan Jelínek. V kontaktu se syntaktiky Jaroslavem Bauerem a jeho žákem Miroslavem Greplem jsem si uvědomila, jak mi scházejí základy školské syntaxe, syntaktikem nemohu být a k oboru mám stále daleko. Nemá však smysl zde nabízet výčet jmen, stejně nelze připomenout všechny.

GB: A polonistyka?

MK: Polština jako samostatný obor neexistovala, bylo ji možno studovat jen jako „třetí obor" s malým počtem hodin a spíše v podobě lektorských kurzů. Nicméně jsem díky ní získala širší slavistický základ. Je mi líto, že jsem nevyužila možnosti absolvovat něco málo z jihoslovanských jazyků, to mi dodnes chybí.

\section{GB: Jaka byla dalsza droga Pani Profesor po skończeniu studiów?}

MK: Naše studium bylo pouze učitelské, i když př́prava na profesi byla pochybná a skoro jen teoretická. Nikdy jsem do školské služby nenastoupila, v r. 1962 jsem byla přijata ke dvouletému studijnímu pobytu na Ústavu pro jazyk český a po něm k interní aspirantuře. Orientace brněnského pracoviště byla dialektologická, měla jsem možnost být účastna sběru jazykového materiálu pro Česky jazykový atlas, který spatřil světlo světa až v 90 . letech minulého století. Kontakt s živým jazykovým materiálem pod vedením zkušených dialektologů, především Jana Balhara, mi dal neocenitelný základ pro další odborné působen a bohatil mě i lidsky. Bohužel mi nebylo dáno u dialektologie zůstat, život občas s námi zatočí.

GB: Co Pani Profesor ma na myśli?

MK: Jak je obecně známo, po „vstupu vojsk” došlo v letech 1969-1970 ke kádrování, které i na fakultě vedlo $\mathrm{k}$ tomu, že někteří lidé, $\mathrm{v}$ době pražského jara aktivní, museli fakultu opustit. Na jazykovědné bohemistice to byl prof. Milan Jelínek, který „,byl odejit” na odborné místo do Ústavu pro jazyk český. A tak nás vyměnili, on dostal místo neodpovídající jeho kvalifikaci a já musela jít na fakultu, stát se odbornou asistentkou. Naštěstí jsem už v té době trošku učila fonetiku, o níž mě zasvětil prof. Karel Ohnesorg; toho nesmím mezi učiteli opomenout. Jako romanista musel učit i fonetiku ruštiny, kterou mi rád předal, později přibyla fonetika češtiny, pro niž se mi empirická znalost zvukové stavby, ovšem 
vnímaná a hodnocená jen sluchově, velmi hodila. Fonetiku a základy fonologie jsem pak učila dlouho, nejen českou, ale i ruskou, pak i obecnou, a to i pro anglisty a jiné mě vzdálené jazyky. Tu jsem naštěstí mohla v tomto tisíciletí předat na obecné lingvistice mladému kolegovi PhDr. Aleši Bičanovi, Ph.D. Na jiných oborech se teorie fonetiky a fonologie prolíná s výukou až nácvikem výslovnosti, omezuje se často na popis a systematiku izolovaných hlásek, což je skutečně nepř́ijemné omezení. Pokud vím, je to podobně i na jiných fakultách.

GB: Fonetyczką jednak Pani Profesor się nie czuje. Wskazuje na to wykaz publikacji. Czy to przypadek?

MK: Není, tento obor se postupně stále více technizuje a heuristická práce v něm vyžaduje vybavení, což jsme neměli. Právě velmi rozsáhlá empirická znalost materiálu mě vede i dnes k názoru, že zobecnění na základě experimentu, byt' propracovaného a ve výsledku krásného i v prezentaci, je vždy jen dílčí a skutečné rozmanité realitě odpovídá právě jen zobecněně. Ovšem - obor jsem učila, vypracovala pro něj skripta a učebnice, které vycházejí dodnes. Nejsou zjednodušující, vysokoškolská výuka přece nesmí být opakováním několika časem prověřených tezí, ale cestou k poznání světa. Bohužel se moje nejnovější práce stává podkladem pro „opory”, tedy shrnutí poznatků s otázkami k látce určené pro potřeby vysokoškolského studia - spíš ale ,ad usum delphini”. A to mě bolí, ale nemohu tomu nijak čelit. Také jsem zpracovala pasáž o zvukové stavbě češtiny pro brněnskou kolektivní Př́ručni mluvnici češtiny z r. 1996 a psala fonetická hesla pro Encyklopedický slovnik češtiny a navázala na to hesly v Novém encyklopedickém slovníku češtiny z r. 2016. V heslech ovšem nejde o heuristický úkol, ale o shrnutí podnětů a poznatků literatury - nejen české - a prezentaci tak, aby byla uživatelsky př́stupná, at' už se tím myslí cokoli. $\mathrm{V}$ tomto př́padě je $\mathrm{z}$ mého hlediska problém $\mathrm{v}$ tom, že zvuková stavba je často chápána jako něco samozřejmého a je pak u budoucích bohemistů interpretována na podkladě znalostí z první třídy základní školy, protože se jí už pak - bez ohledu na doporučení osnov nebo Rámcových vzdělávacích programů nevěnuje př́liš velká pozornost. Je přece samozřejmá, ne? Pak by byla ovšem zbytečná i gramatika mateřštiny, protože česky mluvíme. Bohužel toto ztotožnění praktické znalosti jazyka s jeho teoretickým uchopením je běžné u laiků a ti pak z této pozice hodnotí i lingvistické uchopení češtiny. Kromě toho se mnohým z nich jazyk zjednodušuje na pravopis. To myslím není problém jen české situace. A navíc - v knize lze o zvukové stavbě pojednat jen písemně, tedy bez autentického zvuku. Čelila jsem tomu speciálním multimediálním skriptem dostupným z http://is.muni.cz/elportal, které je určeno jako základ pro všechny filologické obory; bohužel vidím, že je náročné, studenti dávají přednost svým zjednodušením, která si vzájemně dříve opisovali, ted' ,stahuji', a už nejsem s to tento př́stup změnit. Pak se ovšem stane u bakalářské zkoušky, že adept nerozliší písmeno od hlásky. Jenže - proč si stýskám? Co jsme udělali špatně?

GB: Podkreśla Pani Profesor wielokrotnie, że każde poznanie powinno opierać sie na solidnych podstawach. Chodzi o podstawy materiałowe czy metodologiczne?

MK: Oboje, filolog bez znalosti jazykového materiálu včetně vědomí jeho hranic může sice oslňovat (zejména cizince), ale ne docházet ke skutečným závěrům. Materiál někdy člověka pěkně ,postaví do latě”, donese neočekávaná fakta, a pak platí, že teorie má faktům odpovídat, že nelze fakta omezit podle teorie, at už převzaté, nebo vytvořené samostatně. A tím přejdeme k metodologii: Myslím si, že filolog musí mít základ v jediné metodologii, třeba dnes málo módní. Tuto metodologii opouští, pokud neumožní interpretovat zjištěná fakta (tedy nikoli proto, že neodpovídá dobové módě), modifikuje ji, je si vědom jejích kladů i záporů. Protože nic není ideální a ne každá metodologie vyhovuje cíli práce. Pokud bych pracovala $v$ historické mluvnici, bylo by samozřejmé poznat př́mo jazyk co nejvíce textů, i když pro vlastní studie využiju navíc různé databáze, korpusy vlastní nebo vytvořené institucionálně. To platí i pro současný jazyk, jen těžko však určíme, jaké texty by mohly být základem pro poznání. Kdysi se $\mathrm{v}$ této souvislosti mluvilo o spisovném jazyce, ale komunikace se děje ve všech varietách jazyka a omezení je kontraproduktivní. To respektuje i Český národní korpus, který zachycuje texty psané a dnes i mluvené a stále se rozrůstá. Ve zpracování je dostupný pro další práci, ale já přece jen dávám přednost vlastnímu poznání na základě textů, které je živé právě tím kontaktem s nimi a s mou individuální percepcí. Pro zpracování je samozřejmě nutné zobecnění a je nutno odlišovat jazyk jako systém od výběru jednotlivých prvků, které popisuju. Ty ale žijí jen $\mathrm{v}$ textech a navíc i ty texty žijí v komunikaci a na začátku a na konci tohoto procesu jsou lidé - tvưrci, uživatelé, př́ijemci sděleni a jeho interpreti, nejde tedy pouze o texty, ale o komplexní komunikáty, i když je právě $v$ jejich komplexnosti nedokážeme většinou zcela analyzovat. Hranice mezi langue a parole je teoretickým konceptem, ale realita?

Já jsem byla postavena v r. 1966 před úkol vyrovnat se s tématem „městská mluva” v Brně. Šlo o téma v té době aktuální, a také nové, a tak chyběla metoda, jak je uchopit. Byly tu jen rozvahy, co by kdyby. Kdyby? Představa, že tak složitý organismus, jako je mluva velkého města s jeho sociální strukturou a větším pohybem obyvatelstva, lze zachytit dosavadními dialektologickými př́stupy, nebyla reálná, nebylo možno najít reprezentanta mluvy, typického mluvčího, a mluvu velké skupiny mluvčích, která by byla odrazem struktury obyvatelstva, zase nebylo v lidských silách popsat, zvláště když každý z nich komunikoval a komunikuje velmi různorodě podle situace. O generačním a sociálním složení nemluvě. Musela jsem si tedy inspirována svou nevelkou dialektologickou zkušeností při nářečním výzkumu podle dotazníku vytvořit vlast- 
ní dotazník a obrátit se na vybranou generaci - školáky vyšších ročníků. Zpracování velkých čísel responzí, tehdy poměrně pracné, ukázalo tendence v jazykovém povědomí a nepřímo i stav a odvozeně i spontánní mluvy kolem roku 1970. Metoda se ukázala jako nosná, byla užita i některými dalšími kolegy a umožnila i mě při zachování metodiky zadávání otázek ukázat posun v jazykovém povědomí v odstupu jedné generace. Bohužel už u další generace nejsem s to zkoumat, tazatel mého věku už mladé respondenty nepřiměje $\mathrm{k}$ tomu, aby reagovali spontánně.

GB: Brno i jego mowa stały się przedmiotem prac Pani Profesor także później, na co wskazuje obszerna bibliografia publikacji z tego zakresu.

MK: Původně jsem se zajímala o zvukovou stavbu a morfologii mluvy mého města, ale jeho slovní zásoba mě doslova donutila, abych se jí zabývala. Nechtěla jsem se věnovat tzv. hantecu, specifickému výrazivu spojovanému pokud jde o původ s dřívějšími okrajovými společenskými vrstvami, které je nejen mimo Brno, ale i samými Brňany pokládáno za jeho specifikum, zaujala mě však lexika sociálně neomezená, která se utvářela v bilingvním prostředí. Je možné, že podobné lexikum existovalo i v jiných místech, ale nikdo mu nevěnoval pozornost a v průběhu 20. století zmizelo. Podařilo se mi na základě různých zdrojů včetně náhodných soukromých zápisků vytvořit vlastní slovníček přes 1000 výrazů $\mathrm{v}$ různých modifikacích, zatím však je $\mathrm{v}$ mých poznámkách, protože zpracování materiálu potřebuje i značné lexikologické a lexikografické zkušenosti, které nemám. Snad to ještě stihnu udělat, protože tento materiál by těžko mohl někdo bez mého podílu prezentovat. Od takové výrazně nespisovné mluvy středních vrstev pak je jen krůček $\mathrm{k}$ hantecu, ale ten mě zajímal jako předmět sociolingvistického studia, nikoli tedy jako zdroj zábavy. V tom se neshoduju $\mathrm{s}$ těmi, kteří i dnes hantec rozvíjejí k radosti své i ostatních. Snad i proto se ostýchám mu věnovat více pozornosti - není to moje mluva ani moje prostředí.

GB: Przechodzimy zatem do kolejnych dziedzin, którymi Pani Profesor się zajmowala.

MK: Přechod na fakultu mě postavil před další úkoly. Po vynuceném odchodu prof. Jelínka zůstala opuštěna stylistika, která do profilu studia českého jazyka patří. Přednášek se ujal prof. Chloupek, semináre jsem postupně dostala já. A bylo to (a dodnes je) obtížné: Co mám vlastně dělat? Věnovat se korekci studentských textů? Pak by bylo možno pokračovat $\mathrm{v}$ tom, co se dělá na střední škole, ale na vysoké škole? Není samozřejmě možno popírat didaktickou orientaci stylistiky, ale to je jen maličká, i když tradicí prověřená část oboru. Musela jsem si postupně studiem i vlastními úvahami ověřit, co je to vlastně styl a co může stylistika ve vysokoškolském studiu ukázat. Postupně jsem si to urovnávala a výsledky vtělila do studií, a hlavně do kapitol kolektivních děl - cyklu stylistik kolektivu M. Čechová, J. Chloupek, E. Minářová a já. Původní koncepci jsme formovali s Janem Chloupkem a v knihách jsme se dělili všichni čtyři o kapitoly. Jsou autorské a čím dál tím více vidím, že jsou i metodicky různorodé. Asi bych měla psát stylistiku vlastní, prezentovat vcelku vlastní koncepci oboru, ale budu na to mít ještě sílu? Stylistice jsem věnovala i kapitolu v Dějinách české jazykovědné bohemistiky a v některých heslech Nového encyklopedického slovníku češtiny z r. 2016 - v něm jsem je zdědila s úkolem aktualizovat po M. Jelínkovi. Stylistika je přitom disciplína nesmírně zajímavá, je totiž na rozdíl od např. indoevropeistiky oborem, který se stále prudce vyvíjí, mění se jeho materiálová základna, př́stupy, souvisí do jisté míry i s proměnami kultury a nakonec, na rozdíl od jiných filologických disciplín, s technickými možnostmi doby: desítky nových typů textů, které se vytvářejí spolu s internetovou komunikací nejrůznejjšího typu, jsou toho dokladem. Nevystačíme tedy v oboru s tím, co platilo včera, ovšem minulost je stále př́tomna a nové vzniká ve vztahu k tradičnímu. Je to vše třeba znát a vnímat v souvislostech. Otevřenost stylistiky je fascinující nejen pro mne.

GB: Szereg stylistycznych prac Pani Profesor zostało opublikowanych także w Polsce.

MK: Ano, a za tuto možnost děkuji zase M. Jelínkovi, který tu měl kontakty ještě z dob před r. 1990 a seznámil mě s prof. Gajdou z Opole, který organizoval slavistické konference zaměřené na stylistiku a byl hlavním hybatelem založení časopisu „Stylistyka”, který má už dnes (2019) XXVIII ročník. Účast na konferencích mi ukázala, jak různorodé pohledy na obor mohou existovat a kde lze hledat obecné principy. Od roku 1995 pak učím stylistiku na Ústavu jazykovědy a baltistiky FF MU. Zde už nikoli tradiční českou stylistiku, která směřuje ke kvalitní stylizaci v češtině, ale stylistiku obecnou, která hledá tendence, která neulpívá na spisovnosti textu a která se ve svém důsledku stává naukou o komunikaci nejen verbální.

GB: Czy tam można poszukiwać początków zainteresowania stratyfikacją języka narodowego?

MK: Částečně to má na svědomí ten dialektologický počátek, částečně je tu i patrný nedostatek povědomí o struktuře českého národního jazyka u některých lingvistů-nebohemistů - je toho více. Ale asi je podstatná ta stylistika: Stylistik potřebuje mít jako základ všech svých zobecnění nadhled - nad komunikací, jazykem v komunikaci, nad mluvou jako konkrétní realizací systému, nad společností, již jazyk slouží. Není tedy odborníkem v jednotlivých lingvistických disciplínách, nestuduje detaily, ale všechny potřebuje znát, aby mohl k zobecnění dojít. Vracím se tak vlastně $\mathrm{k}$ dialektologii, která mi zůstala blízká, i když jsem se jí nikdy nemohla věnovat. Rozpracování modelu stratifikace jazyka, který je obecný, ale musí být dokládán češtinou (obecné věci vždy musíme doložit; já to i na obecné jazykovědě musím dělat na češtině, protože 
studenti, i ti zahraniční, studují v tomto jazyku a doklady např. z dialektů arabštiny opravdu nemohu sloužit), jsem publikovala doma i v zahraničí.

GB: Także w publikacjach zbiorowych?

MK: Ano, asi je mým osudem být členkou kolektivů, takže vlastní monografii mám vlastně jen jednu, a to už dávnou. Nevím, zda je nutno úzce vymezené monografie mít, i když dnes se bez ní nedá habilitovat, o profesuře nemluvě. Pořád se domnívám, že vědecká práce je věcí přirozeně se utvářejícího kolektivního bádání a vzájemné interakce odborníků, která stojí proti „,fachidiocii“. Asi i v tom je dávný základ mé odborné specializace, protože dialektologie, zejména práce na Ceském jazykovém atlasu nemohla být dílem jedince; výzkum i zpracování probíhalo v kolektivu získávajícím materiál, kde se museli všichni postupně sjednotit $\mathrm{v}$ přístupu $\mathrm{k}$ respondentům a vlastně $\mathrm{i} \mathrm{v}$ zaměření jednotlivých otázek, jež jim kladli, společně vyjížděli „,do terénu”, společně diskutovali nad postupně se upřesňujícími způsoby prezentace atd. V tom měli hlas nejen starší a zkušení dialektologové. Zpracování materiálu už pak bylo hlavně v rukou další generace, jak ukazuje i doba, která uplynula od základních sběrů materiálu, tedy od 60. let minulého století, do let, kdy svazky vycházely (1992-2011). Takže kontinuita nejen v prostoru, ale i v čase.

GB: Pani Profesor posiada grono swoich uczniów, którzy kontynuują rozwój nauki w tym zakresie. Co może Pani o nich powiedzieć?

MK: Jistě, studentů za ty roky bylo nespočetně, ale ne všichni byli výrazní. Byli nejen v Brně, ale i Bratislavě, v Opavě a v Ostravě, kde jsem všude na filozofických fakultách po roce 1990 dočasně působila. Na vysoké škole ostatně bohužel vidíme své studenty často jen jeden semestr, tedy v ideálním případě 12 lekcí, $z$ toho třeba něco odpadne nebo student nepřijde. Víte sama, že to pro vytvoření skutečného vztahu učitele a žáka nemůže stačit. Lepší je to při vedení diplomních prací, kde se už setkáváme nad konkrétním tématem. Na bohemistice jsem samozřejmě diplomní práce vedla, ale $\mathrm{z}$ diplomandů mi ne všichni utkvěli $\mathrm{v}$ paměti. Je to nakonec už dávno. $\mathrm{V}$ poslední době mám $\mathrm{v}$ paměti bohemistu pana Holaje, který pracoval nad tématem Počítačová podpora osvojování české výslovnosti. Technické stránce jeho tématu, které si sám vymyslel, jsem nerozuměla, ale samo uchopení fonetické látky a možnost její aplikace byla i pro mne inspirující. Tento student, dnes už magistr, v tématu pokračuje, ovšem už na informatice. Snad se ještě dozvím k čemu došel. A veliký zájem Mgr. Petra Malčíka o tradice fonetického bádání. Na obecné jazykovědě, odkud jsem odešla do důchodu, už jsem měla diplomantů minimum, protože jsem bohemistka a na oboru studují i zahraniční studenti, kteří bohemistická témata těžko mohou zpracovávat. V doktorandském studiu je sice kontakt větší, ale zase spíš nárazový, student si vybírá téma, konzultuje je, ale pak pracuje samostatně a nakonec, protože mnohdy už je někde zaměstnán, spíše koriguji jeho pokusy o odbornost zpracování a vyjádření. Kromě toho nemám představu, jakým směrem se bude jeho život dále ubírat - snažím se totiž téma a jeho zaměření koordinovat s tím, kde absolvent najde uplatnění. Ovšem pro absolventa filologie je takových možností málo. Z mých „žákư” se uplatnili na Ústavu pro jazyk český doktorky Ireinová, Šipková, a hlavně Stanislava Kloferová, dialektoložka, jejiž studie mají ohlas nejen u nás, ale i v německy mluvících zemích, nebo PhDr. Martin Schacherl, Ph.D., působící dnes v Ceských Budjovicích a PhDr. Lujza Urbancová, Ph.D., v Banské Bystrici. A měla bych připomenout ty, kdo převzali můj obor: Na obecné jazykovědě je to už zmíněný dr. Aleš Bičan, Ph.D., který převzal obecnou fonetiku, ten však není mým př́mým žákem. Převzal i sociolingvistiku, i když ta není v centru jeho odborné pozornosti. Má však proti mně výhodu, že je také anglista, takže mu studium anglicky psané literatury, dnes pro obor nezbytné, nečiní potíže. Na bohemistice jsem naštěstí měla komu stylistiku předat. Dr. Michal Kř́stek, Ph.D., M. Phil., se postupně chopil tvưrčím způsobem oboru, dnes už převzal i mou doktorandku a jsem přesvědčena, že jeho publikační činnost doma i v zahraničí přinese své ovoce. Mám i absolventy na jiných fakultách v ČR i na Slovensku, ale vypočítávat je zde by nemělo smysl.

GB: Wypowiedzi Pani Profesor mają charakter podsumowujący, ale widać w nich też, że wybiega Pani Profesor także w przyszlość. Jakie zatem ma Pani plany?

MK: Jistě, to je samozřejmé. Už jsme narazily na to, že dnes vidím, co jsem mohla udělat lépe nebo co by bylo dobře ještě dokončit. Nevím ovšem, kolik mi je dáno času a sil, ale pokusím se. Moji dnešní kolegové na Ústavu jazykovědy a baltistiky FF MU, který jsem spolu s prof. Erhartem r. 1995 zakládala, zejména jeho dnešní vedoucí indoevropeista PhDr. Ondřej Šefč́í, Ph.D., mi vytvářejí dobré podmínky, mám také př́istup $\mathrm{k}$ literatuře $\mathrm{v}$ rozsahu, který „za mého mládí” nebyl, počítač usnadňuje práci. Poměrně dost času věnuji dnes recenzni činnosti, která má smysl spíše u rukopisu než u hotového textu - jeho nedostatky už změnit nejde, u rukopisu je to reálné a je možno eventuální „připodotýkaní" prodiskutovat. Komentuju, někdy bohužel (bohudík?) i poněkud neortodoxně. To pisatele mnohdy naštve, pokud je však rozumný, a to ti, kdo mi rukopis dají $\mathrm{k}$ nahlédnutí, jsou, po počátečním rozčilení popřemýšlí a vyvaruje se nepomyšlených úvah a vyjádření. A pokud ne? Každý svého štěstí strůjcem. Dnes se mi zdá, že př́stup k obrovskému objemu sekundární literatury způsobuje, že ji pisatel sleduje jen velmi kurzoricky a že okouzlen novými metodami objevuje s jejich využitím věci, které už jsou dávno známé. Jsme zas u toho, že pro filologa je podstatná znalost materiálu, a pak také tradic oboru, abychom s novou „světovou” terminologií nesdělovali věci dávno známé nebo pro jazyk velmi nepodstatné. Jenže - kdo má začátečníkovi něco takového sdělit než 
právě důchodkyně, už nezávislá na nikom a na ničem, jen na svém svědomí. My na sklonku životní dráhy musíme být i takovým svědomím oboru.

GB: Pani Profesor,dziękuję bardzo za niezwykle ciekawą i pouczającą rozmowę. Życzymy Pani sił i zdrowia na dalsze lata, spełnienia planów, kolejnych sukcesów w pracy naukowej oraz aby nadal towarzyszyła Pani Profesor ta wyjątkowa pasja badawcza do odkrywania nowych obszarów lingwistyki. 